\title{
KEBIJAKAN PEMERINTAH KABUPATEN KUDUS DI BIDANG PENYELENGGARAAN PENDIDIKAN DASAR PADA ERA OTONOMI DAERAH
}

\section{Subarkah dan Bisri}

\begin{abstract}
ABSTRAK
Kebijakan Pemerintah Kabupaten Kudus di bidang penyelenggaraan pendidikan dasar adalah menjadikan penyelenggaraan pendidikan dasar sebagai salah satu prioritas pembangunan sebagaimana disebutkan dalam Peraturan Daerah Kabupaten Kudus Nomor 11 Tahun 2008 tentang Rencana Pembangunan Jangka Panjang Daerah (RPJPD) Kabupaten Kudus Tahun 2005 - 2025 dan Peraturan Daerah Kabupaten Kudus Nomor 5 Tahun 2009 tentang Rencana Pembangunan Jangka Menengah Daerah (RPJMD) Kabupaten Kudus Tahun 2008 - 2013, serta menindaklanjutinya melalui penerbitan Peraturan Daerah yang khusus mengatur tentang penyelenggaraan pendidikan dasar, yaitu melalui penerbitan Peraturan Daerah Kabupaten Kudus Nomor 2 Tahun 2010 tentang Wajib Belajar 12 (Dua Belas) Tahun.

Kendala internal yang muncul berkaitan dengan kebijakan Pemerintah Kabupaten Kudus di bidang penyelenggaraan pendidikan dasar adalah masih minimnya anggaran yang dialokasikan untuk penyelenggaraan pendidikan dasar dan belum diterbitkannya petunjuk atau peraturan pelaksanaan yang menindaklanjuti Peraturan Daerah Kabupaten Kudus Nomor 2 Tahun 2010 tentang Wajib Belajar 12 (Dua Belas) Tahun kepada masyarakat. Selanjutnya kendala eksternal yang muncul berkaitan dengan kebijakan Pemerintah Kabupaten Kudus di bidang penyelenggaraan pendidikan dasar adalah masih adanya masyarakat yang belum memahami arti pentingnya pendidikan dan masih kurangnya peran aktif masyarakat dalam penyelenggaraan pendidikan dasar di Kabupaten Kudus.
\end{abstract}

Kata Kunci: Kebijakan, Pemerintah, Pendidikan Dasar

\section{PENDAHULUAN}

Sejalan dengan tujuan Negara Republik Indonesia sebagaimana diamanatkan dalam Pembukaan Undang-Undang Dasar Negara Republik Indonesia Tahun 1945 alinea ke 4, yaitu melindungi segenap bangsa Indonesia dan seluruh tumpah darah Indonesia dan untuk memajukan kesejahteraan umum, mencerdaskan kehidupan bangsa dan ikut melaksanakan kemerdekaan, perdamaian abadi dan keadilan sosial, maka pemerintah Negara Republik Indonesia berkewajiban mengupayakan 
kecerdasan bangsa dan meningkatkan kualitas manusia Indonesia dalam mewujudkan masyarakat yang maju, adil dan makmur serta memungkinkan para warganya mengembangkan diri baik berkenan dengan aspek jasmaniah maupun rohani berdasarkan Pancasila dan Undang-Undang Dasar Negara Republik Indonesia Tahun 1945.

Upaya pemerintah Negara Republik Indonesia di bidang pendidikan tersebut di atas, kembali dipertegas dalam ketentuan Pasal 28C Undang-Undang Dasar Negara Republik Indonesia Tahun 1945, dimana disebutkan bahwa setiap orang berhak mengembangkan diri melalui pemenuhan kebutuhan dasarnya, berhak mendapat pendidikan dan memperoleh manfaat dari ilmu pengetahuan dan teknologi, seni dan budaya, demi meningkatkan kualitas hidupnya dan demi kesejahteraan umat manusia.

Sebagai tindaklanjut ketentuan Pasal 28C Undang-Undang Dasar Negara Republik Indonesia Tahun 1945 tersebut di atas, dan sekaligus dalam upaya memberikan pedoman penyelenggaraan pendidikan di Indonesia, pemerintah telah menerbitkan peraturan perundang-undangan yang khusus mengatur tentang penyelenggaraan pendidikan di Indonesia, yaitu Undang-Undang Nomor
20 Tahun 2003 tentang Sistem Pendidikan Nasional.

Secara hakiki, pembangunan pendidikan merupakan bagian yang tidak dapat dipisahkan dalam pembangunan manusia. Upaya-upaya pembangunan di bidang pendidikan pada dasarnya diarahkan untuk mewujudkan kesejahteraan manusia iru sendiri. Hal ini dikarenakan pendidikan merupakan hak setiap warga negara sebagaimana diamanatkan oleh ketentuan Pasal 28C Undang-Undang Dasar Negara Republik Indonesia Tahun 1945.

Disebutkan dalam Pasal 1 butir 1 Undang-Undang Nomor 20 Tahun 2003, bahwa yang dimaksud dengan pendidikan adalah usaha sadar dan terencana untuk mewujudkan suasana belajar dan proses pembelajaran agar peserta didik secara aktif mengembangkan potensi dirinya untuk memiliki kekuatan spiritual keagamaan, pengendalian diri, kepribadian, kecerdasan, akhlak mulia, serta keterampilan yang diperlukan dirinya, masyarakat, bangsa dan negara.

Selanjutnya untuk menjamin terlaksananya penyelenggaraan pendidikan, Undang-Undang Nomor 20 Tahun 2003 melalui ketentuan Pasal 5 ayat (1) menyatakan bahwa setiap warga negara mempunyai hak yang sama untuk 
memperoleh pendidikan yang bermutu.

Adapun ukuran atau standar mutu layanan pendidikan di sini telah diatur secara khusus dalam Keputusan Menteri Pendidikan Nasional Nomor 129a/U/2004 tentang Standar Pelayanan Minimal Bidang Pendidikan.

Selain sebagai hak, pendidikan juga bersifat wajib bagi warga negara yang berusia tujuh tahun sampai dengan lima belas tahun. Hal ini adalah sebagaimana disebutkan dalam ketentuan Pasal 6 ayat (1) UndangUndang Nomor 20 Tahun 2003, yang menyatakan bahwa setiap warga negara yang berusia tujuh sampai dengan lima belas tahun wajib mengikuti pendidikan dasar.

Berpijak pada ketentuan tersebut di atas, dapat ditarik pengertian bahwa Undang-Undang Nomor 20 Tahun 2003 memberikan jaminan kepastian hukum dalam penyelenggaraan pendidikan dasar, yaitu dengan mewajibkan warga negara yang berusia tujuh sampai dengan lima belas tahun untuk mengikuti pendidikan dasar.

Terbitnya Undang-Undang Nomor 20 Tahun 2003 juga telah merubah konsep penyelenggaraan pendidikan dari yang bersifat sentralistik menjadi desentralistik. Konsep desentralisasi pendidikan tersebut di atas adalah seiring dengan pemberlakukan Undang-
Undang Nomor 32 Tahun 2004 tentang Pemerintahan Daerah yang memberikan kewenangan kepada Pemerintah Daerah untuk menyelenggarakan pelayanan pendidikan. $^{1}$

Desentralisasi pendidikan merupakan suatu keharusan yang didasarkan pada tiga hal, yaitu (1) pembangunan masyarakat demokrasi; (2) pengembangan social capital; dan (3) peningkatan daya saing bangsa. Ketiga hal tersebut sudah lebih dari cukup untuk dijadikan alasan mengapa desentralisasi pendidikan harus dilakukan oleh bangsa Indonesia. ${ }^{2}$

Pemerintah daerah memiliki peran penting dalam penyelenggaraan pendidikan dasar, yaitu menyelenggarakan secara penuh pendidikan dasar. Adapun sebagai pedoman pelaksanaan penyelenggaraan pendidikan dasar oleh Pemerintah Daerah, telah diterbikan Peraturan Menteri Pendidikan Nasional Nomor 50 Tahun 2007 tentang Standar Pengelolaan Pendidikan Oleh Pemerintah Daerah. Pelaksanaan peran pemerintah daerah dalam penyelenggaraan pendidikan dasar tersebut tentunya diwujudkan melalui

\footnotetext{
${ }^{1}$ Sam M. Chan dan Tuti T. Sam, "Kebijakan Pendidikan Era Otonomi Daerah”, Rajawali Pers, Jakarta, 2005, hal 1.

${ }^{2}$ H.A.R. Tilaar, "Membenahi Pendidikan Nasional", Rineka Cipta, Jakarta, 2002, hal 20.
} 
kebijakannya atau yang sering disebut dengan kebijakan publik pemerintah daerah.

Demikian pula yang dilakukan oleh Pemerintah Daerah Kabupaten Kudus, yang mencantumkan penyelenggaraan pendidikan dasar sebagai salah satu prioritas kegiatan. Berbagai bentuk kebijakan telah dilakukan dalam upaya meningkatkan penyelenggaraan pendidikan dasar di wilayah Kabupaten Kudus. Secara keseluruhan, dengan motto "Pendidikan Terjangkau dan Berkualitas Melalui Wajib Belajar 12 Tahun", Pemerintah Daerah Kabupaten Kudus berupaya meningkatkan kualitas penyelenggaraan pendidikan dasar di Kabupaten Kudus.

Di satu sisi, kebijakan Pemerintah Daerah Kabupaten Kudus di bidang penyelenggaraan pendidikan dasar dianggap telah berhasil dengan baik. Hal ini dibuktikan dengan diraihnya penghargaan Satya Lencana Bidang Pendidikan dari Presiden Susilo Bambang Yudhoyono. ${ }^{3}$ Namun di sisi lain, masih terdapat anggapan bahwa apa yang dilakukan oleh Pemerintah Daerah Kabupaten Kudus di bidang pendidikan tersebut hanyalah fiktif dan bermuatan politis saja. Masih terdapat

\footnotetext{
${ }^{3}$ Muhammad Oliez, "Beri Pelayanan Bernilai Lebih, Tarif Jelas dan Tepat Waktu”, www.seputarindonesia.com, Diakses April 2011.
}

pertanyaan yang menanyakan tentang bentuk dan realisasi kebijakan Pemerintah Daerah Kabupaten Kudus di bidang penyelenggaraan pendidikan dasar. Apalagi pada saat ini di Kabupaten Kudus sedang merebak keberadaan Rintisan Sekolah Bertaraf Internasional (RSBI) dimana biaya yang dipungut lebih tinggi, sehingga memunculkan opini masyarakat bahwa pendidikan di Kabupaten Kudus pada saat mahal biayanya dan hanya orangorang yang mampu saja yang memperoleh pendidikan yang baik.

\section{Kebijakan Pemerintah Kabupaten Kudus di Bidang Penyelenggaraan Pendidikan Dasar}

Kebijakan Pemerintah Kabupaten Kudus di bidang penyelenggaraan pendidikan dasar pada dasarnya telah dicanangkan dalam Rencana Pembangunan Jangka Panjang Daerah (RPJPD) Kabupaten Kudus, yakni sebagaimana terangkum dalam Peraturan Daerah Kabupaten Kudus Nomor 11 Tahun 2008 tentang Rencana Pembangunan Jangka Panjang Daerah (RPJPD) Kabupaten Kudus Tahun 2005 2025.

Disebutkan dalam Peraturan Daerah Kabupaten Kudus Nomor 
11 Tahun 2008, bahwa pembangunan di sektor pendidikan untuk tahun 2005 - 2005 diarahkan untuk mewujudkan:

a. peningkatan pemerataan akses dan mutu pendidikan dasar dan menengah, wajib belajar serta peningkatan relevansi dan kompetensi pendidikan sesuai dengan kebutuhan masyarakat dan pangsa kerja;

b. peningkatan pelayanan pendidikan semua jalur, jenis, dan jenjang pendidikan yang berorientasi pada IPTEK;

c. Pengembangan kualitas perpustakaan daerah.

\section{Berdasarkan}

Rencana

Pembangunan Jangka Panjang Daerah (RPJPD) Kabupaten Kudus sebagaimana terangkum dalam Peraturan Daerah Kabupaten Kudus Nomor 11 Tahun 2008 tersebut di atas, terlihat bahwa penyelenggaraan pendidikan dasar merupakan salah satu prioritas pembangunan di Kabupaten Kudus. hal tersebut kembali dipertegas dalam Rencana Pembangunan Jangka Menengah Daerah (RPJMD) Kabupaten Kudus untuk tahun 2008 - 2013 yang tertuang dalam Peraturan Daerah Kabupaten Kudus Nomor 5 Tahun 2009 tentang
Rencana Pembangunan Jangka

Menengah Daerah (RPJMD)

Kabupaten Kudus Tahun 2008 2013.

Rencana Pembangunan Jangka Menengah Daerah (RPJMD) Kabupaten Kudus untuk tahun 2008 - 2013 tersebut di atas disusun atas dasar hasil monitoring dan evaluasi terhadap penyelenggaraan pendidikan pada tahun $2004-2007$, yang selengkapnya sebagai berikut; ${ }^{4}$

Berdasarkan Profil Pendidikan Tahun 2007 diketahui bahwa dari jumlah seluruh penduduk Kabupaten Kudus, proporsi penduduk yang tidak/belum pernah sekolah sebanyak 64.214 orang $(8,74 \%)$, tidak/belum tamat SD sebanyak 154.704 orang (21,05\%), tamatan SD sebanyak 268.400 orang $(36,52 \%)$, tamat SMP sebesar 103.311 orang $(14,06 \%)$, tamat SMA sebanyak 68.546 orang (9,33\%), dan tamatan Diploma III ke atas sebesar 42.013 orang $(3,66 \%)$.

Berdasarkan data tersebut di atas, terlihat bahwa proporsi pendidikan penduduk Kabupaten Kudus terbesar adalah tamatan SD yakni sebesar $36,52 \%$ dan proporsi

\footnotetext{
${ }^{4}$ Lampiran Peraturan Daerah Kabupaten Kudus Nomor 5 Tahun 2009.
} 
tersebut semakin menurun dengan semakin tingginya jenjang pendidikan. Sementara itu angka buta aksara penduduk usia 15 tahun ke atas masih sebesar 78.713 orang $(10,7 \%)$. Kondisi tersebut belum memadai untuk menghadapi persaingan global dan belum mencukupi pula sebagai landasan pengembangan ekonomi berbasis pengetahuan (knowledge based economy).

Tahun 2003 sampai dengan tahun 2007 Angka Partisipasi Kasar (APK) SD/MI mencapai antara 85,61 - 98,69\%, (tuntas paripurna) namun Angka Partisipasi Murni (APM) baru mencapai antara 70,02 - 79,59\%. APK SMP/MTs mencapai 94,46 - 101,24\% (tuntas paripurna), namun APM baru mencapai $68.62-70,28 \%$ sedangkan APK SMA/MA/SMK baru mencapai antara 67,01$70,85 \%$ (belum tuntas paripurna), dan APM baru mencapai antara antara 44,94- 48,41\%. Sedangkan Angka Patisipasi Sekolah (APS) dalam periode yang sama untuk SD/MI sangat fluktuatif, tahun 2003 sebesar 90,31\%, 2004 98,24\%, 2005 96,07\%, 2006 92,27\% dan tahun 2007 sebesar 91,86\%. APS untuk SMP/MTs dalam 5 (lima) tahun terakhir terus mengalami kenaikan, tahun 2003 sebesar 70,56\%, 2004 meningkat menjadi 86,54\%, 2005 90,03\%, $200691,51 \%$ dan tahun 2007 sebesar 93,84.

Namun untuk SMA/SMK/MA, meskipun terus mengalami kenaikan, APS masih belum optimal, yaitu pada tahun 2003 sebesar 41,63\%, 2004 sebesar 46,64\%, 2005 sebesar 49,41\%, 2006 sebesar 50,63\%, dan tahun 2007 meningkat menjadi $52,79 \%$. Sementara itu angka putus sekolah untuk SD/MI tahun 2003 sebesar 1,71\%, 2004 sebesar 0,18\%, 2005 turun menjadi 0,11\%, 2006 menjadi 0,04\%, dan tahun 2007 meningkat menjadi $0,05 \%$. Sedangkan angka putus sekolah SMP/MTs lebih tinggi dibandingkan dengan SD/MI, yaitu pada tahun 2003 sebesar 1,01\%, 2004 sebesar 1,21\%, 2005 dan 2006 sebesar $0,86 \%$ dan tahun 2007 sebesar 0,93\%. Angka putus sekolah untuk SMA/SMK/MA pada tahun 2004 sebesar 1,31\%, 2005 dan 2006 sebesar 1,59\%, dan 2007 turun menjadi $0,85 \%$.

Penurunan jumlah penduduk usia muda terutama kelompok usia 7-12 tahun sebagai dampak positif program Keluarga Berencana menyebabkan turunnya jumlah 
siswa yang bersekolah pada jenjang SD/MI dari tahun ke tahun. Hal tersebut terus dipertimbangkan dalam menyediakan fasilitas pelayanan pendidikan sehingga efisiensi dapat terus ditingkatkan. Masih banyak sekolah-sekolah (SD) yang jumlah siswanya tidak memenuhi Standart Pelayanan Minimal, bahkan terdapat 109 Sekolah Dasar yang jumlah siswanya kurang dari 70 anak (hasil pendataan Bappeda Kabupaten Kudus tahun 2006), dan yang lebih menjadikan perhatian ada sekolah yang jumlah murid dalam satu kelas kurang dari 10 anak. Disamping turunnya jumlah siswa sebagaimana tersebut di atas, pada saat yang sama terjadi peningkatan proporsi penduduk usia dewasa yang berdampak pada perlunya untuk terus mengembangkan penyediaan layanan pendidikan formal yang terjangkau dan berkualitas sampai tingkat sekolah menengah atas, dan layanan pendidikan non formal untuk memberi pelayanan pendidikan sesuai kebutuhan mereka. Kualitas pendidikan juga relatif masih rendah dan belum mampu memenuhi kebutuhan kompetensi peserta didik. Hal tersebut terutama disebabkan oleh ketersediaan pendidik yang berkualitas belum memadai, dan fasilitas belajar belum tersedia secara mencukupi.

Berdasarkan data profil pendidikan Kabupaten Kudus tahun 2007 menunjukkan bahwa belum penyelenggaraan pendidikan dasar yang dicanangkan oleh Pemerintah Daerah Kabupaten Kudus melalui program wajib belajar 12 tahun walaupun secara umum menunjukkan peningkatan kualitas, namun masih belum sesuai yang diharapkan. Hal tersebut khususnya dilihat dari masih adanya anak usia wajib belajar yang mengalami putus sekolah, bahkan jumlahnya lebih meningkat daripada tahun-tahun sebelumnya.

Berpijak dari kenyataan di atas, Pemerintah Daerah Kabupaten Kudus terus berupaya untuk meningkatkan penyelenggaraan pendidikan dasar di Kabupaten Kudus dengan jalan memberikan landasan hukum yang jelas dan tegas serta khusus mengatur tentang penyelenggaraan pendidikan dasar di Kabupaten Kudus sebagai tindaklanjut dari Peraturan Daerah Kabupaten Kudus Nomor 11 Tahun 2008 tentang Rencana Pembangunan Jangka Panjang 
Daerah (RPJPD) Kabupaten Kudus

Tahun 2005 - 2025 dan Peraturan

Daerah Kabupaten Kudus Nomor 5

Tahun 2009 tentang Rencana

Pembangunan Jangka Menengah

Daerah (RPJMD) Kabupaten Kudus

Tahun 2008 - 2013. Hal tersebut diwujudkan melalui penerbitan Peraturan Daerah Kabupaten Kudus Nomor 2 Tahun 2010 tentang Wajib Belajar 12 (Dua Belas) Tahun.

Peraturan Daerah Kabupaten

Kudus Nomor 2 Tahun 2010 tentang Wajib Belajar 12 (Dua Belas) Tahun telah mengatur secara lengkap mengenai penyelenggaraan pendidikan dasar, mulai dari ketentuan umum, maksud dan tujuan, penyelenggaraan, pengelolaan, hingga sampai penjaminan pendanaan. Disebutkan dalam ketentuan Pasal 1 butir 7 Peraturan Daerah Kabupaten Kudus Nomor 2 Tahun 2010, bahwa yang dimaksud dengan wajib belajar 12 (dua belas) tahun adalah program pendidikan minimal yang harus diikuti oleh penduduk Kabupaten Kudus atas tanggungjawab Pemerintah, Pemerintah Daerah, dan Masyarakat.

Selanjutnya disebutkan dalam ketentuan Pasal 2 Peraturan Daerah Kabupaten Kudus Nomor 2 Tahun
2010, bahwa Peraturan Daerah ini dibentuk dengan maksud untuk memberikan dasar hukum bagi penyelenggaraan Wajib Belajar 12 (dua belas) tahun dengan tujuan meningkatkan perluasan dan pemerataan memperoleh pendidikan minimal sampai ke jenjang pendidikan menengah bagi penduduk Kabupaten Kudus.

Berdasarkan kedua ketentuan Peraturan Daerah Kabupaten Kudus Nomor 2 Tahun 2010 tersebut di atas, dapat ditarik pengertian bahwa Pemerintah Kabupaten Kudus melalui penerbitan Peraturan Daerah Kabupaten Kudus Nomor 2 Tahun 2010 berusaha menjamin terselenggaranya pendidikan dasar di Kabupaten Kudus. Hal ini dipertegas kembali dalam ketentuan Pasal 8 Peraturan Daerah Kabupaten Kudus Nomor 2 Tahun 2010 yang menyatakan bahwa penduduk Kabupaten Kudus yang berusia 7 (tujuh) sampai dengan 18 (delapan belas) tahun wajib mengikuti program wajib belajar 12 (dua belas) tahun.

Selanjutnya Pasal 3 Peraturan Daerah Kabupaten Kudus Nomor 2 Tahun 2010 menyebutkan bahwa

(1) Wajib belajar 12 (dua belas) tahun diselenggarakan pada 
jalur pendidikan formal, pendidikan non formal, dan pendidikan informal.

(2) Penyelenggaraan wajib belajar 12 (dua belas) tahun pada jalur pendidikan formal dilaksanakan minimal pada jenjang pendidikan dasar yang meliputi SD, MI, SMP, MTs, dan bentuk lain yang sederajat, sampai dengan pendidikan menengah yang meliputi SMA, MA, SMK, MAK dan bentuk lain yang sederajat.

(3) Penyelenggaraan wajib belajar 12 (dua belas) tahun pada jalur pendidikan non formal dilaksanakan melalui program paket A, program paket B, sampai dengan program paket C dan bentuk lain yang sederajat.

(4) Penyelenggaraan wajib belajar 12 (dua belas) tahun pada jalur pendidikan informal dilaksanakan melalui pendidikan keluarga dan/atau pendidikan lingkungan.

(5) Ketentuan mengenai penyetaraan pendidikan non formal dan pengakuan hasil pendidikan informal penyelenggaraan program wajib belajar 12 (dua belas) tahun terhadap pendidikan menengah jalur formal berpedoman pada peraturan perundang-undangan yang mengatur tentang penyelenggaraan dan pengelolaan pendidikan.

Berdasarkan ketentuan Pasal 3 Peraturan Daerah Kabupaten Kudus Nomor 2 Tahun 2010 tersebut di atas, dapat ditarik pengertian bahwa penyelenggaraan pendidikan dasar di Kabupaten Kudus dilakukan di semua sektor, baik sektor formal, non formal, maupun sektor informal. Kesemua sektor penyelenggaraan pendidikan dasar di Kabupaten Kudus tersebut diselenggarakan oleh Disdikpora Kabupaten Kudus bekerjasama dengan pihak-pihak terkait, namun semuanya di bawah koordinasi Disdikpora Kabupaten Kudus demi untuk menyatukan misi dan visi penyelenggaraan pendidikan dasar di Kabupaten Kudus.

Selanjutnya disebutkan dalam ketentuan Pasal 7 Peraturan Daerah Kabupaten Kudus Nomor 2 Tahun 2010, bahwa:

(1) Satuan pendidikan dasar dan satuan pendidikan menengah, 
penyelenggara program wajib belajar 12 (dua belas) tahun wajib menjaga keberlangsungan pelaksanaan program wajib belajar 12 (dua belas) tahun yang berkualitas dan terjangkau.

(2) Satuan pendidikan dasar dan satuan pendidikan menengah, penyelenggara program wajib belajar 12 (dua belas) tahun wajib menerima peserta didik program wajib belajar 12 (dua belas) tahun tanpa diskriminasi sesuai daya tampung satuan pendidikan yang bersangkutan.

(3) Penerimaan peserta didik pada satuan pendidikan dasar sebagaimana dimaksud pada ayat (2) pada SD/MI atau yang sederajat tidak mempersyaratkan bahwa calon peserta didik yang bersangkutan telah menyelesaikan pendidikan anak usia dini.

Berpijak pada ketentuan Pasal 7 Peraturan Daerah Kabupaten Kudus Nomor 2 Tahun 2010 tersebut di atas, terlihat jelas bahwa Pemerintah Kabupaten Kudus dalam penyelenggaraan pendidikan juga mengedepankan kualitas dengan biaya terjangkau oleh masyarakat, serta tanpa adanya diskriminasi sama sekali. Memang diakui bahwa untuk pengertian kualitas dan terjangkau tersebut memang relatif dan tidak ada patokannya. Hal ini juga yang sering menjadi perdebatan di tengah-tengah masyarakat Kabupaten Kudus. Patut dipahami bahwa kondisi sosial masyarakat Kabupaten Kudus yang heterogen memang menjadikan ukuran kualitas dan terjangkau tersebut sangat variatif, tergantung siapa yang berbicara.

Bagi kalangan masyarakat Kabupaten Kudus yang tergolongan mampu dimana sebagian besar bersekolah di sekolah-sekolah unggulan (RSBI), merasa puas dengan layanan pendidikan dasar di Kabupaten Kudus. Hal tersebut adalah sebagaimana hasil kuesioner yang disebarkan kepada 10 (sepuluh) orang masyarakat dari perwakilan orang tua murid di sekolah-sekolah unggulan (RSBI), dimana semuanya atau sebanyak $100 \%$ menyatakan bahwa kualitas pendidikan di Kabupaten Kudus cukup memuaskan dan terjangkau oleh masyarakat. 
Namun tidak demikian dengan masyarakat dari golongan menengah ke bawah yang umumnya bersekolah di sekolah-sekolah biasa. Dari hasil kuesioner yang dilakukan terhadap $10 \quad$ (sepuluh) orang masyarakat dari perwakilan orang tua murid di sekolah-sekolah biasa, sebanyak 8 (delapan) responden atau sebanyak $80 \%$ menyatakan bahwa penyelenggaraan pendidikan dasar di Kabupaten Kudus masih pilih-pilih (diskriminatif), hanya orang-orang yang mampu saja yang memperoleh pendidikan berkualitas. Selanjutnya mengenai biaya sekolah yang terjangkau, semua responden menyatakan terjangkau namun dianggap kurang berkualitas. Dalam keterangannya, semua responden pada umumnya menyatakan bahwa pengertian terjangkau dimaksud adalah untuk memperoleh layanan pendidikan pas-pasan atau dengan kualitas biasa, tapi kalau menginginkan kualitas yang lebih baik mereka menyatakan tidak mampu karena harus masuk sekolah-sekolah unggulan.

Lebih lanjut, kebijakan Pemerintah Kabupaten Kudus dalam penyelenggaraan pendidikan dasar adalah memberikan jaminan kepada masyarakat Kabupaten
Kudus untuk memperoleh pendidikan dasar. Hal tersebut adalah sebagaimana tertuang dalam ketentuan Pasal 8 Peraturan Daerah Kabupaten Kudus Nomor 2 Tahun 2010, yaitu bahwa:

(1) Penduduk Kabupaten Kudus yang berusia 7 (tujuh) sampai dengan 18 (delapan belas) tahun wajib mengikuti program wajib belajar 12 (dua belas) tahun.

(2) Penduduk Kabupaten Kudus yang berusia di atas 18 tahun dan belum lulus pendidikan menengah dapat menyelesaikan pendidikannya sampai lulus.

(3) Penduduk Kabupaten Kudus yang berusia 7 (tujuh) sampai dengan 18 (delapan belas) tahun yang putus sekolah dan/atau tidak lulus pendidikan dasar dan/atau pendidikan menengah wajib menyelesaikan pendidikannya sampai lulus.

(4) Penduduk Kabupaten Kudus usia wajib belajar 12 (dua belas) tahun yang orang tua/walinya berasal dari keluarga miskin dan tidak mampu membiayai pendidikan dan/atau yang menjadi anak asuh yang bertempat tinggal di 
panti asuhan, wajib

tetapi belum memperoleh menyelesaikan pendidikannya sampai jenjang pendidikan menengah.

(5) Ketentuan mengenai orang tua/wali yang berasal dari keluarga miskin dan tidak mampu membiayai pendidikan sebagaimana dimaksud pada ayat (4) diatur lebih lanjut oleh Bupati.

(6) Pemerintah Daerah wajib memberikan beasiswa sesuai kemampuan keuangan daerah kepada peserta didik untuk menyelesaikan pendidikan sebagaimana dimaksud pada ayat (2), ayat (3), dan ayat (4).

(7) Pemerintah Daerah sesuai kewenangannya dapat memberikan bea siswa kepada peserta didik yang berprestasi.

Ketentuan Pasal 8 Peraturan Daerah Kabupaten Kudus Nomor 2 Tahun 2010 tersebut di atas jelasjelas memberikan jaminan kepada semua warga Kabupaten Kudus, tanpa kecuali untuk memperoleh layanan pendidikan dasar. Namun demikian dalam pelaksanaannya masih kurang maksimal. Masih banyak masyarakat Kabupaten Kudus yang usia pendidikan dasar

kesempatan mengenyam pendidikan dasar. Hal tersebut disebabkan oleh banyak faktor, salah satunya adalah faktor ekonomi. Namun demikian, secara internal di lingkungan Disdikpora Kabupaten Kudus, penyebab masih banyaknya masyarakat Kabupaten Kudus usia pendidikan dasar tetapi belum memperoleh kesempatan mengenyam pendidikan dasar adalah kurang luasnya daya pantau Disdikpora Kabupaten Kudus dan kurangnya peran aktif dari masyarakat untuk ikut memantau pelaksanaan pendidikan dasar di Kabupaten Kudus.

Selanjutnya mengenai jaminan layanan pendidikan dasar bagi keluarga miskin dan tidak mampu membiayai pendidikan dan/atau yang menjadi anak asuh yang bertempat tinggal di panti asuhan, hal ini juga telah direalisasikan oleh Pemerintah Kabupaten Kudus. Hingga tahun 2011 berjalan ini, tercatat sebanyak 4.415 siswa yang memperoleh bea siswa dengan jumlah nominal mencapai Rp. 1.840.390.00,- dari Pemerintah Kabupaten Kudus, dan pemberian bea siswa ini menjadi agenda rutin dari Pemerintah 
Kabupaten Kudus dalam setiap setahun sekali.

Kemudian lebih lanjut disebutkan dalam Pasal 9 Peraturan Daerah Kabupaten Kudus Nomor 2 Tahun 2010 bahwa Pemerintah Daerah sesuai dengan kewenangannya menjamin tersedianya biaya operasional untuk Penyelenggaraan Program Wajib Belajar 12 (dua belas) tahun. Jaminan biaya operasional ini diwujudkan melalui alokasi anggaran pendidikan yang telah disediakan di APBD. Untuk diketahui bahwa pada dasarnya Undang-Undang Nomor 20 Tahun 2003 tentang Sistem Pendidikan Nasional dalam ketentuan Pasal 49 ayat (1) telah mewajibkan kepada Pemerintah dan Pemerintah Daerah untuk mengalokasikan anggaran sebesar $20 \%$ ke sektor pendidikan. Namun ketentuan tersebut hingga kini masih belum dapat diwujudkan, umumnya anggaran yang dialokasikan ke sektor pendidikan oleh pemerintah-pemerintah daerah masih jauh dari yang ditentukan undang-undang. Demikian pula di Kabupaten Kudus, besaran anggaran yang dialokasikan untuk program pendidikan dasar tahun anggaran 2010 adalah sebesar Rp.
32.805.807.000,00 (tiga puluh dua milyar delapan ratus lima juta delapan ratus tujuh ribu rupiah) dari total pendapatan daerah sebesar Rp. 767.177.505.000,00 (tujuh ratus enam puluh tujuh milyar seratus tujuh puluh tujuh juta lima ratus lima ribu rupiah) atau hanya sebesar 4,27 \%. Namun demikian perlu dipahami bahwa apabila melihat kondisi APBD Kabupaten Kudus yang sedang defisit dan Pemerintah Kabupaten Kudus berani mengalokasikan anggaran pendidikan sebesar tersebut, tentunya menunjukkan bahwa Pemerintah Kabupaten Kudus benar-benar serius dalam melaksanakan program wajib belajar 12 tahun.

Berdasarkan hasil penelitian terhadap kebijakan Pemerintah Kabupaten Kudus di bidang penyelenggaraan pendidikan dasar sebagaimana diuraikan di atas, dapat ditarik pengertian bahwa kebijakan Pemerintah Kabupaten Kudus di bidang penyelenggaraan pendidikan dasar adalah menjadikan penyelenggaraan pendidikan dasar sebagai salah satu prioritas pembangunan sebagaimana disebutkan dalam Peraturan Daerah Kabupaten Kudus Nomor 11 Tahun 
2008

tentang

Rencana

Pembangunan Jangka Panjang

Daerah (RPJPD) Kabupaten Kudus

Tahun 2005 - 2025 dan Peraturan

Daerah Kabupaten Kudus Nomor 5

Tahun 2009 tentang Rencana

Pembangunan Jangka Menengah

Daerah (RPJMD) Kabupaten Kudus

Tahun 2008 - 2013, serta

menindaklanjutinya melalui

penerbitan Peraturan Daerah yang

khusus mengatur tentang

penyelenggaraan pendidikan dasar,

yaitu melalui penerbitan Peraturan

Daerah Kabupaten Kudus Nomor 2

Tahun 2010 tentang Wajib Belajar

12 (Dua Belas) Tahun.

Peraturan Daerah Kabupaten

Kudus Nomor 2 Tahun 2010

tentang Wajib Belajar 12 (Dua

Belas) Tahun tersebut mengatur secara lengkap mengenai penyelenggaraan pendidikan dasar, mulai dari ketentuan umum, maksud dan tujuan, penyelenggaraan, pengelolaan, hingga sampai penjaminan pendanaan.

Hal tersebut di atas adalah sejalan dengan pengertian dari kebijakan daerah itu sendiri yang berarti aturan, arahan, dan pedoman dalam penyelenggaraan pemerintahan daerah yang dituangkan dalam peraturan daerah atau keputusan kepala daerah.

Dalam negara hukum, setiap pembuatan kebijakan pemerintahan harus senantiasa bersendikan hukum, produk-produknya harus dimuat dalam kemasan hukum. Demikian pula dalam halnya sistem pemerintahan daerah, maka setiap perbuatan kebijakan pemerintahan daerah yang baru, baik berupa keputusan kepala daerah maupun peraturan daerah, senantiasa harus bersendikan hukum. Demikian pula dalam kebijakan Pemerintah Kabupaten Kudus dalam penyelenggaraan pendidikan dasar yang dikemas dalam sebuah peraturan daerah, yaitu Peraturan Daerah Kabupaten Kudus Nomor 2 Tahun 2010 tentang Wajib Belajar 12 (Dua Belas) Tahun, yang penerbitannya mengacu pada peraturan perundang-undangan di atasnya, yaitu Undang-Undang Nomor 20 Tahun 2003 tentang Sistem Pendidikan Nasional, khususnya ketentuan Pasal 11 yang menyatakan bahwa kewajiban pemerintah dan pemerintah daerah dalam penyelenggaraan pendidikan adalah memberikan layanan dan kemudahan serta menjamin terselenggaranya pendidikan yang 
bermutu bagi setiap warga negara tanpa diskriminasi, wajib menjamin tersedianya dana guna terselenggaranya pendidikan bagi setiap warga negara yang berusia tujuh sampai dengan lima belas tahun.

Dengan demikian terhadap hasil penelitian dan pembahasan tentang kebijakan Pemerintah Kabupaten Kudus di bidang penyelenggaraan pendidikan dasar tersebut di atas, dapat ditarik kesimpulan bahwa kebijakan Pemerintah Kabupaten Kudus di bidang penyelenggaraan pendidikan dasar adalah menjadikan penyelenggaraan pendidikan dasar sebagai salah satu prioritas pembangunan sebagaimana disebutkan dalam Peraturan Daerah Kabupaten Kudus Nomor 11 Tahun 2008 tentang Rencana Pembangunan Jangka Panjang Daerah (RPJPD) Kabupaten Kudus Tahun 2005 - 2025 dan Peraturan Daerah Kabupaten Kudus Nomor 5 Tahun 2009 tentang Rencana Pembangunan Jangka Menengah Daerah (RPJMD) Kabupaten Kudus Tahun 2008 - 2013, serta menindaklanjutinya melalui penerbitan Peraturan Daerah yang khusus mengatur tentang penyelenggaraan pendidikan dasar, yaitu melalui penerbitan Peraturan Daerah Kabupaten Kudus Nomor 2 Tahun 2010 tentang Wajib Belajar 12 (Dua Belas) Tahun.

Penerbitan Peraturan Daerah Kabupaten Kudus Nomor 2 Tahun 2010 tentang Wajib Belajar 12 (Dua Belas) Tahun tersebut di atas sekaligus sebagai dasar hukum dalam pemberian layanan dan kemudahan serta menjamin terselenggaranya pendidikan yang bermutu bagi setiap warga negara tanpa diskriminasi, dan menjamin tersedianya dana guna terselenggaranya pendidikan bagi setiap warga negara yang berusia tujuh sampai dengan lima belas tahun sebagaimana diamanatkan oleh Pasal 11 Undang-Undang Nomor 20 Tahun 2003 tentang Sistem Pendidikan Nasional.

\section{Kendala-kendala yang Muncul} Berkaitan Dengan Kebijakan Pemerintah Kabupaten Kudus di Bidang Penyelenggaraan Pendidikan Dasar

Apabila mencermati hasil penelitian dan pembahasan pada sub bab terdahulu yang mengulas tentang kebijakan Pemerintah Kabupaten Kudus di bidang 
penyelenggaraan pendidikan dasar, dapat ditarik pengertian adanya beberapa kendala yang muncul, yaitu masih banyaknya anak usia pendidikan dasar yang tidak mengenyam pendidikan dasar, kurangnya peran aktif masyarakat dalam penyelenggaraan program wajib belajar, adanya anggapan dari sebagian masyarakat mengenai diskriminasi dalam penyelenggaraan pendidikan dasar, dan masih minimnya alokasi dana yang dianggarkan untuk pendidikan dasar. Namun demikian untuk mengetahui benar tidaknya kendalakendala tersebut, berikut disampaikan hasil penelitian yang telah dilakukan;

Mengenai masih banyaknya anak usia pendidikan dasar yang tidak mengenyam pendidikan dasar, dari hasil pendataan yang dilakukan oleh Disdikpora Kabupaten Kudus, hingga akhir tahun 2010 hanya terdapat sebesar $0,03 \%$ saja. Artinya jumlah tersebut tidak dapat dikatakan banyak, khususnya apabila dibandingkan dengan tahun sebelumnya yang jumlahnya sebesar $0,12 \%$. Hal tersebut disebabkan oleh banyak faktor, khususnya adalah rendahnya kesadaran orang tua terhadap arti pentingnya pendidikan. Akibat rendahnya kesadaran orang tua terhadap arti pentingnya pendidikan, menjadikan orang tua tidak memperdulikan pendidikan anak-anaknya.

Selanjutnya mengenai kurangnya peran aktif masyarakat dalam penyelenggaraan pendidikan dasar di Kabupaten Kudus, peran serta masyarakat dalam penyelenggaraan program wajib belajar di Kabupaten Kudus masih jauh dari yang diharapkan, bahkan masyarakat terkesan pasif atau tidak mau tahu mengenai penyelenggaraan program wajib belajar. Padahal pengertian peran aktif masyarakat dalam penyelenggaraan program wajib belajar tidak ada kaitannya dengan pendanaan, masyarakat cukup ikut mengawasi dan melaporkan kepada Disdikpora dalam hal terdapat ketimpangan dalam penyelenggaraan program wajib belajar atau dalam hal terdapat anak usia pendidikan dasar yang tidak bersekolah.

Hal tersebut di atas juga dibenarkan oleh kalangan masyarakat pemerhati pendidikan. Dari hasil kuesioner yang dilakukan terhadap 10 (sepuluh) orang masyarakat dari perwakilan 
pemerhati pendidikan di Kabupaten

Kudus diperoleh keterangan bahwa saat ini perhatian masyarakat terhadap penyelenggaraan pendidikan dasar sangat rendah. Lebih lanjut, dari hasil kuesioner juga dapat diketahui bahwa rendahnya partisipasi masyarakat terhadap penyelenggaraan program wajib belajar adalah disebabkan ketidaktahuan masyarakat terhadap mekanisme atau tata cara pelaksanaan partisipasi masyarakat tersebut dalam penyelenggaraan program wajib belajar. $^{5}$

Ketidakpahaman masyarakat terhadap mekanisme atau tata cara pelaksanaan partisipasi masyarakat tersebut dalam penyelenggaraan program wajib belajar tersebut disebabkan karena memang Peraturan Daerah Kabupaten Kudus Nomor 2 Tahun 2010 tentang Wajib Belajar 12 (Dua Belas) Tahun tersebut belum banyak disosialisasikan mengingat belum ada petunjuk atau peraturan pelaksanaannya. Sosialisasi keberadaan Peraturan Daerah Kabupaten Kudus Nomor 2 Tahun 2010 tentang Wajib Belajar 12 (Dua

\footnotetext{
${ }^{5}$ Hasil kuesioner terhadap 10 (sepuluh) orang masyarakat dari perwakilan pemerhati pendidikan di Kabupaten Kudus.
}

Belas) Tahun baru dilaksanakan di lingkungan pendidikan saja, belum dilakukan secara meluas kepada masyarakat umum.

Ketentuan Pasal 11 Peraturan Daerah Kabupaten Kudus Nomor 2 Tahun 2010 mewajibkan kepada masyarakat untuk ikut berperan serta dalam penyelenggaraan program wajib belajar 12 tahun. Namun sayangnya dalam ketentuan tersebut tidak dijelaskan bentukbentuk peran serta yang menjadi kewajiban masyarakat itu sendiri, sehingga ketentuan tentang kewajiban masyarakat untuk ikut berperan serta dalam penyelenggaraan program wajib belajar 12 tahun tersebut masih kabur dan belum dapat dilaksanakan dengan baik. Artinya, terhadap ketentuan Pasal 11 Peraturan Daerah Kabupaten Kudus Nomor 2 Tahun 2010 tersebut di atas dibutuhkan petunjuk atau peraturan pelaksanaannya.

Selanjutnya mengenai kendala masih minimnya alokasi dana yang dianggarkan untuk pendidikan dasar di Kabupaten Kudus, walaupun dana yang dialokasikan masih minim, tetapi tekad Pemerintah Daerah Kabupaten Kudus untuk mensukseskan program wahib 
belajar 12 tahun sangat kuat, sehingga harapan untuk memperoleh hasil yang maksimal masih dimungkinkan.

Kemudian mengenai kendala yang terakhir, yaitu adanya anggapan dari sebagian masyarakat mengenai diskriminasi dalam penyelenggaraan pendidikan dasar, hal tersebut jelas-jelas disanggah oleh pihak Disdikpora Kabupaten Kudus bahwa tidak ada diskriminasi sedikitpun dalam penyelenggaraan program wajib belajar 12 tahun di Kabupaten Kudus, tetapi yang ada hanyalah perbedaan fasilitas dan perlakuan antara di sekolah-sekolah unggulan dan di sekolah-sekolah biasa. Patut dipahami bahwa hal tersebut merupakan kewenangan dan pengelolaan internal sekolah. Bukan hanya di sekolah-sekolah unggulan, di sekolah-sekolah biasa juga ada yang memberikan fasilitas dan perlakuan yang baik, jadi semua itu tergantung pada manajemen masing-masing sekolah. Pihak Disdikpora jelas-jelas sudah memberikan arahan kepada semua sekolah mengenai larangan adanya diskriminasi dan bahkan mewajibkan sekolah-sekolah yang ada di Kabupaten Kudus untuk memberikan tempat atau menerima siswa dari kalangan kurang mampu yang jumlahnya telah ditentukan, yaitu minimal $10 \%$ dari jumlah seluruh siswa yang diterima.

Berdasarkan hasil penelitian terhadap kendala-kendala yang muncul berkaitan dengan kebijakan Pemerintah Kabupaten Kudus di bidang penyelenggaraan pendidikan dasar tersebut dapat ditarik kesimpulan bahwa kendala-kendala yang muncul berkaitan dengan kebijakan Pemerintah Kabupaten Kudus di bidang penyelenggaraan pendidikan dasar terdiri dari kendala internal dan kendala eksternal.

Kendala internal yang muncul berkaitan dengan kebijakan Pemerintah Kabupaten Kudus di bidang penyelenggaraan pendidikan dasar adalah masih minimnya anggaran yang dialokasikan untuk penyelenggaraan pendidikan dasar dan belum diterbitkannya petunjuk atau peraturan pelaksanaan yang menindaklanjuti Peraturan Daerah Kabupaten Kudus Nomor 2 Tahun 2010 tentang Wajib Belajar 12 (Dua Belas) Tahun kepada masyarakat. Selanjutnya kendala eksternal yang muncul berkaitan dengan kebijakan Pemerintah Kabupaten Kudus di bidang penyelenggaraan pendidikan dasar adalah masih adanya 
masyarakat yang belum memahami arti pentingnya pendidikan dan masih kurangnya peran aktif masyarakat dalam penyelenggaraan pendidikan dasar di Kabupaten Kudus.

\section{A. Simpulan}

1. Kebijakan Pemerintah Kabupaten Kudus di bidang penyelenggaraan pendidikan dasar adalah menjadikan penyelenggaraan pendidikan dasar sebagai salah satu prioritas pembangunan sebagaimana disebutkan dalam Peraturan Daerah Kabupaten Kudus Nomor 11 Tahun 2008 tentang Rencana Pembangunan Jangka Panjang Daerah (RPJPD) Kabupaten Kudus Tahun 2005 - 2025 dan Peraturan Daerah Kabupaten Kudus Nomor 5 Tahun 2009 tentang Rencana Pembangunan Jangka Menengah Daerah (RPJMD) Kabupaten Kudus Tahun 2008 - 2013, serta menindaklanjutinya melalui penerbitan Peraturan Daerah yang khusus mengatur tentang penyelenggaraan pendidikan dasar, yaitu melalui penerbitan Peraturan Daerah Kabupaten Kudus Nomor 2 Tahun 2010 tentang Wajib Belajar 12 (Dua Belas) Tahun.
Penerbitan Peraturan Daerah Kabupaten Kudus Nomor 2 Tahun 2010 tentang Wajib Belajar 12 (Dua Belas) Tahun tersebut di atas sekaligus sebagai dasar hukum dalam pemberian layanan dan kemudahan serta menjamin terselenggaranya pendidikan yang bermutu bagi setiap warga negara tanpa diskriminasi, dan menjamin tersedianya dana guna terselenggaranya pendidikan bagi setiap warga negara yang berusia tujuh sampai dengan lima belas tahun sebagaimana diamanatkan oleh Pasal 11 Undang-Undang Nomor 20 Tahun 2003 tentang Sistem Pendidikan Nasional.

2. Kendala internal yang muncul berkaitan dengan kebijakan Pemerintah Kabupaten Kudus di bidang penyelenggaraan pendidikan dasar adalah masih minimnya anggaran yang dialokasikan untuk penyelenggaraan pendidikan dasar dan belum diterbitkannya petunjuk atau peraturan pelaksanaan yang menindaklanjuti Peraturan Daerah Kabupaten Kudus Nomor 2 Tahun 2010 tentang Wajib Belajar 12 (Dua Belas) Tahun kepada masyarakat. Selanjutnya kendala eksternal yang muncul berkaitan dengan kebijakan Pemerintah Kabupaten Kudus di 
bidang penyelenggaraan pendidikan dasar adalah masih adanya masyarakat yang belum memahami arti pentingnya pendidikan dan masih kurangnya peran aktif masyarakat dalam penyelenggaraan pendidikan dasar di Kabupaten Kudus.

\section{B. Saran}

1. Kepada Pemerintah Kabupaten Kudus, hendaknya segera menerbitkan petunjuk atau peraturan pelaksana yang menindaklanjuti Peraturan Daerah Kabupaten Kudus Nomor 2 Tahun 2010 tentang Wajib Belajar 12 (Dua Belas), sehingga nantinya program wajib belajar 12 tahun di Kabupaten Kudus benar-benar dapat dilaksanakan dengan baik dan mampu mewujudkan layanan pendidikan dasar kepada masyarakat Kabupaten Kudus sesuai yang digariskan oleh Undang-Undang Nomor 20 Tahun 2003 tentang Sistem Pendidikan Nasional.

2. Kepada masyarakat Kabupaten Kudus pada umumnya dan khususnya kepada masyarakat pemerhati pendidikan di Kabupaten Kudus, hendaknya dapat lebih bersikap pro aktif dalam penyelenggaraan pendidikan dasar, sehingga pelaksanaan atau penyelenggaraan pendidikan dasar di Kabupaten Kudus dapat benarbenar berjalan dengan baik dan sesuai yang diharapkan.

\section{Daftar Pustaka}

Abdul Rozak Husein, 2001, "Pedoman Pendidikan Dasar”, Jakarta: Gramedia.

Amran Muslimin, 2002, "Otonomi Daerah dan Daerah Otonom", Jakarta: Bina Cipta.

Arif Nasution, 2000, "Demokrasi dan Problema Otonomi Daerah", Bandung: Mandar Maju.

A. Asri Harahap, 2000, "Pembagian Kekuasaan Pusat dan Daerah ; Pengalaman Masa Lalu dan Idaman Masa Depan”, Bandung: Mandar Maju.

Bambang Sunggono, 1994, "Hukum dan Kebijakan Publik”, Jakarta: Sinar Grafika.

Bratakusumah dan Solihin, 2006, "Kebijakan Publik Dalam Era Otonomi Daerah", PT. Jakarta: Grasindo.

Budi Winarno, 2002, "Kebijakan dan Proses Kebijakan Publik", Yogyakarta: Media Pressindo.

Cholid Narbuko dan Abu Achmadi, 2001, Metodologi Penelitian, Jakarta: Bumi Aksara. 
Dadang Solihin, 2003, "Pemerintahan Daerah”, Jakarta: PT. Gramedia.

Hanif Nurcholis, 2007, 'Teori dan Praktik Pemerintahan Dan Otonomi Daerah”, Jakarta: PT. Grasindo.

H.A.R. Tilaar, 2002, "Membenahi Pendidikan Nasional”, Jakarta: Rineka Cipta.

Kismartini, 2007, "Analisis Kebijakan Publik”, Jakarta: Grafindo Persada.

Mastutu, 2009, "Pemberdayaan Sistem Pendidikan”, Jakarta: Logos.

Moh Uzer Usman, 2005, "Menjadi Guru Profesional", Bandung: Remaja Rosdakarya.

Muchan, 2000, "Otonomi Daerah dan Ketidakadilan Daerah", Bandung: Mandar Maju.

Nugroho, 2003, "Kebijakan Publik; Formulasi, Implementasi, dan Evaluasi”, Jakarta: PT Elex Media Komputindo.

Ridwan HR, 2006, "Hukum Administrasi Negara”, Jakarta: PT. Rajagrafindo Persada.

Ronny Hanitijo Soemitro, 1982, Metodologi Penelitian Hukum, Jakarta: Ghalia Indonesia.

Sam M. Chan dan Tuti T. Sam, 2005, "Kebijakan Pendidikan Era Otonomi Daerah”, Jakarta: Rajawali Pers.
Sarundajang, 2007, "Otonomi Daerah Di Indonesia”, Jakarta: Rajawali.

Soenarjo, 1985, "Metode Riset I", Surakarta: Universitas Negeri Sebelas Maret.

Sutopo dan Sugiyanto, 2001, "Analisis Kebijakan Publik”, Jakarta: LAN RI.

Sutrisno Hadi, 1984, "Metodologi Research”, Jilid I, Yogyakarta: Yayasan Penerbit Fakultas Psikologi UGM.

Syaukani HR, 2003, "Otonomi Daerah Dalam Negara Kesatuan”, Yogyakarta: Pustaka Pelajar. 